\title{
MENINGKATKAN PENGETAHUAN MENGENAI PENANGANAN DIARE PADA ANAK MELALUI PENYULUHAN KESEHATAN
}

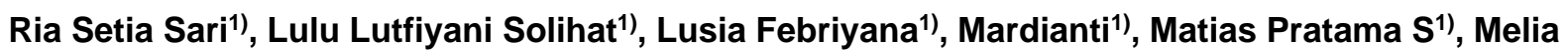 \\ Puspita Sari'), Mirqotussyifa'), Monika Caterina ${ }^{1)}$, Muhamad Rustami'), Muhamad Daetun'), \\ Muhamad Ridwanul P1), Muhamad Yusup'), Nanda Farhani F'), Nesa Ria O'), Novita Rosdiana'), \\ Nurlaelah"1)
}

1)Program Studi Profesi Ners, STIKes Yatsi, Kota Tangerang, Banten, Indonesia

Corresponding author : Ria Setia Sari
E-mail : riasetiasari233@gmail.com

Diterima 13 Januari 2021, Direvisi 05 Februari 2021, Disetujui 06 Februari 2021

\begin{abstract}
ABSTRAK
Diare merupakan gangguan buang air besar dengan frekuensi lebih dari 3 kali sehari, konsistensi cair, bisa disertai darah dan atau lender. Tujuan Kegiatan: Untuk meningkatkan pengetahuan orang tua dalam penanganan diare pada anak dengan benar dan salah satu terapi komplementernya adalah menggunakan madu. Metode Kegiatan: Penyuluhan kesehatan dengan sasaran 15 anak dan orang tua yang dilakukan secara online dengan Google Meet. Hasil Kegiatan: terdapat 14 (93,3\%) orang tua (ayah/ibu) yang memahami mengenai penanganan diare pada anak dan $1(6,6 \%)$ orang tua (ayah/ibu) yang aktif bertanya dalam kegiatan.
\end{abstract}

Kata kunci: diare; anak; penyuluhan kesehatan

\begin{abstract}
Diarrhea is a bowel disorder with a frequency of more than 3 times a day, liquid consistency, can be accompanied by blood and / or mucus. Activity Objective: To increase parents' knowledge in handling diarrhea in children properly and one of the complementary therapies is using honey. Activity Method: Health education targeting 15 children and parents conducted online with Google Meet. Activity Results: there were $14(93.3 \%)$ parents (father / mother) who understood the handling of diarrhea in children and $1(6.6 \%)$ parents (father / mother) who actively asked questions in activities.
\end{abstract}

Key words: diarrhea; children; health education

\section{PENDAHULUAN}

Diare adalah frekuensi pengeluaran dan kekentalan feses yang tidak normal. Menurut WHO diare merupakan buang air besar yang lunak atau cair dengan frekuensi 3 kali atau lebih per hari. Diare biasanya merupakan gejala pada gastrointestinal yang dapat disebabkan oleh berbagai agen infeksi seperti bakteri, virus, dan parasit. Infeksi dapat menular dari makanan yang terkontaminasi daan hygiene yang kurang (Arsurya, 2017).

Penyakit diare merupakan salah satu penyakit paling sering menyerang anak-anak diseluruh dunia termasuk negara berkembang seperti Indonesia. Hal ini dikarenakan angka mordibitas dan mortalitasnya yang masih tinggi. Diperkirakan 4 milyar kasus diare terjadi setiap tahun pada anak balita di seluruh dunia. Setiap tahun 1,5 juta anak balita meninggal karena diare. Diare membawa kematian lebih cepat pada anak-anak dibanding orang dewasa karena terjadinya dehidrasi dan malnutrisi (Humrah, 2018).
Secara meluas terjadi peningkatan kejadian diare dan kematian akibat diare pada balita dari periode tahun 2016-2019. Dari data WHO tahun 2018 menunjukkan hampir 1,7 miliar anak yang mendertita diare dengan angka kematian 525.000 anak setiap tahunnya. Kasus diare yang terjadi di Indonesia tahun 2016 sebesar 2.544.084 (Kemenkes RI, 2017).

Penyakit diare di Indonesia, masih menjadi masalah kesehatan masyarakat bila dilihatdari angka kesakitan dan kematian yang terjadi. Penyakit diare termasuk dalam sepuluh penyakit terbesar. Berdasarkan hasil Riset Kesehatan Dasar (Riskesdas) tahun 2018, kejadian diare pada balita menuru diagonsa di daerah Banten meningkat dari tahun 2013 sebesar 3\% meningkat pada tahun 2018 sebesar 12\% (Riskesdas, 2018).

Tanda dan gejala diare sendiri yaitu pertama bayi dan anak menjadi cengeng, gelisah, suhu tubuh biasanya meningkat, nafsu makan berkurang atau tidak nafsu makan, kemudian timbul diare. Diare yang tidak segera 
ditangani akan menyebabkan tinja semakin lama berubah warna menjadi kehijauan disertai darah. Anusdan daerah sekitar menjadi lecet akibat dari asam laktat yang berasal dari laktosa yang tidak dapat diabsorbsi usus selama diare (Ariani, 2016).

Dalam hal tersebut sangat diperlukan penanganan diare yang benar. Beberapa penanganannya seperti pemberian oralit, gizi kaya nutrisi, rehidarasi intravena dan pemberian zinc. Salah satu terapi komplementer yang dapat menangani diare adalah mengkonsumsi madu. Madu memiliki manfaat yang sangat tinggi khususnya dalam menangani diare, karena madu dapat mengatasi berbagai infeksi yang disebabkan oleh bakteri atau mikroba. Madu memiliki efek antibakteri dan kandungan nutrisi serta dapat mengganti cairan tubuh yang hilang (Nurmaningsih \& Rokhaidah, 2019).

Dari latar belakang diatas membawa peneliti untuk melakukan penyuluhan kesehatan demi meningkatkan pengetahuan orang tua dan anak dalam melakukan penanganan diare pada anak dengan benar.

\section{METODE}

Kegiatan pengabdian masyarakat ini diikuti oleh 15 orang tua dan anak dalam rentang usia 2-16 tahun yang dilakukan secara online melalui Google Meet. Dalam pelaksanaanya, kegiatan penyuluhan terdiri dari beberapa tahap yaitu: pertama, tahap pretest yaitu melakukan tanya jawab seputar materi yang kan diberikan untuk mengatahui sejauh mana pengetahuan awal orang tua mengenai penanganan diare. Kedua, tahap penyuluhan yaitu pemateri menyampaikan materi mengenai penanganan diare dan setelahnya melakukan tanya jawab. Ketiga, tahap demonstrasi yaitu peserta melakukan penanganan diare salah satunya menggunakan madu. Keempat, tahap evaluasi yaitu menanyakan kembali kepada peserta seputar materi yang sudah diberikan.

\section{HASIL DAN PEMBAHASAN}

Kegiatan pengabdian masyarakat pada tanggal 24 Desember 2020. Panitia memperkenalkan diri dan menjelaskan tujuan dari kegiatan yang dilakukan. Pada tahap pertama yaitu tahap pre-test, panitia melakukan tanya jawab kepada peserta seputar penanganan diare dengan benar. Berdasarkan hasil tanya jawab, didapatkan bahwa peserta belum mengetahui penanganan diare yang benar.

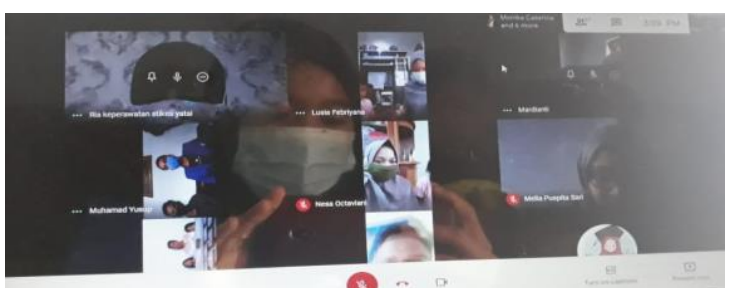

Gambar 1. Tahap Pre-Test Kegiatan Pengabdian Masyarakat

Kegiatan selanjutnya yaitu melakukan penyuluhan kesehatan yang dilakukan oleh panitia. Materi yang diberikan yaitu pengertian diare, cara mengatasi diare cara pemberian madu dan cara pencegahan diare.

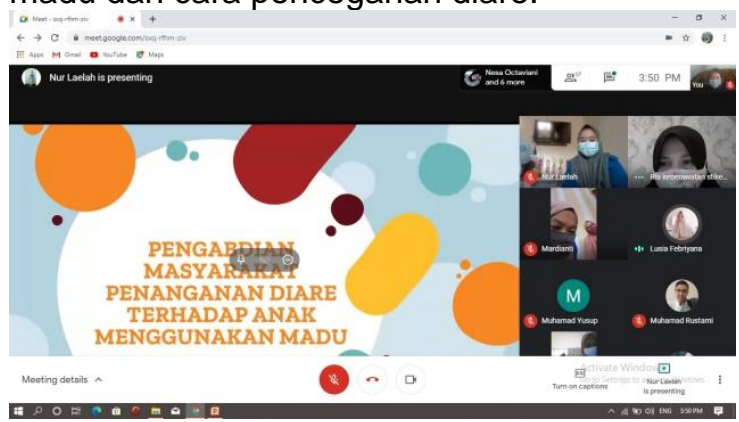

Gambar 2. Tahap Penyuluhan kesehatan Kegiatan Pengabdian Masyarakat

Kemudian, kegiatan berikutnya yaitu demonstrasi dari materi yang telah disampaikan. Demonstrasi yang dilakukan adalah melakukan pemberian madu. Madu diberikan secara oral atau melalui mulut sebanyak $5 \mathrm{cc}$ atau satu sendok makan dalam jumlah $15 \mathrm{~g}$ perhari, terbagi rata dalam $3 \mathrm{x}$ pemberian pada pukul $07.00,15.00$ dan 21.00 efektif dalam mengatasi diare pada anak.

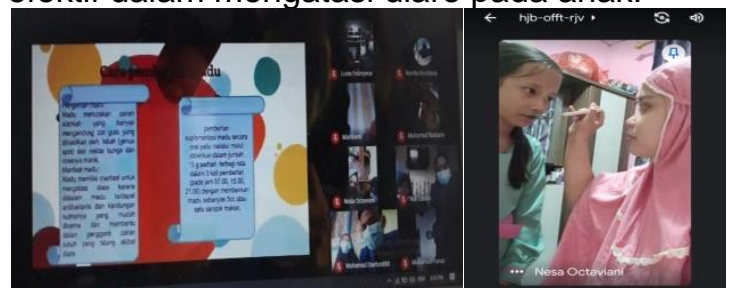

Gambar 3. Tahap Demonstrasi Kegiatan Pengabdian Masyarakat

Tahap terakhir yaitu tahap evaluasi panitia melakukan bertanya kembali seputar materi yang diberikan. Semua peserta dapat menjawab dengan baik pertanyaan yang diberikan dan dapat disimpulkan bahwa peserta sudah mengerti penyuluhan penanganan diare pada anak. 


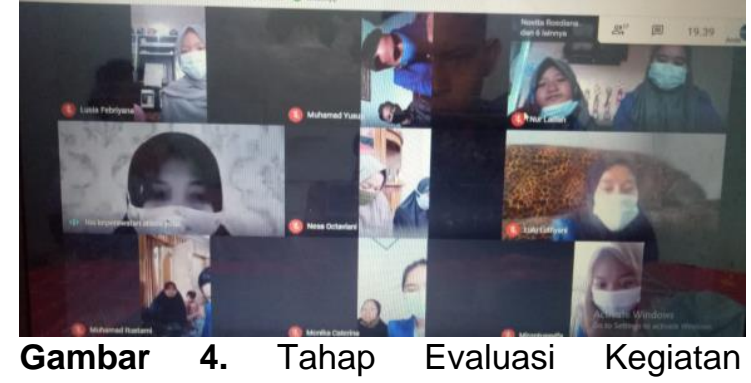

Pengabdian Masyrakat

Penyuluhan kesehatan merupakan rangkaian kegiatan pendidikan kesehatan yang dilakukan dengan memberikan pesan dan menanamkan keyakinan yang bertujuan untuk menambah pengetahuan masyarakat, membuat masyarakat lebih sadar serta bisa melakukan suatu anjuran yang berhubungan dengan kesehatan (Yunadi \& Engkartini, 2020). Dalam penyuluhan kesehatan yang diberikan ada beberapa cara yang dapat dilakukan dalam menangani diare yaitu mengatasi diare dengan memberikan oralit, memberikan zinc, dan memberikan makanan yang sehat dan ASI yang cukup serta memberikan terapi komplementer yaitu pemberian madu.

Pemberian cairan dalam kondisi tidak sedang dehidrasi adalah memberikan larutan oralit dengan osmolaritas rendah yaitu sebanyak $10 \mathrm{ml} / \mathrm{kgbb}$ tiap BAB. Pada sehidrasi ringan-sedang diberikan sesuai dengan berat badan penderita yaitu sebanyak $75 \mathrm{ml} / \mathrm{KgBB}$ dan pada $B A B$ berikutnya sebanyak 10 $\mathrm{ml} / \mathrm{KgBB}$. Berikan ASI pada bayi yang masih mengkonsumsi Air Susu Ibu (ASI) (Simona Ciccarell et al., 2013). Oralit adalah pertolongan pertama yang dapat digunakan untuk mengatasi dehidrasi karena diare. Angka kematian yang tinggi akibat sering tidak teratasinya masalah kekurangan cairan dalam tubuh membuat oralit menjadi pilihan pertama dalam mengganti cairan elektrolit tubuh yang hilang (Nursa'in, 2017).

Selain oralit, menangani diare dapat dilakukan dengan memberikan zinc. Zinc terbukti dapat menurunkan jumlah buang air besar dan volume tinja serta mengurangi resiko dehidrasi. Selain itu zinc juga dapat mencegah terjadinya diare kembali. Walaupun diare sudah sembuh, zinc dapat dibeikan sengan dosis 10 $\mathrm{mg} /$ hari untuk usia $<6$ tahun (Soenarto, 2011). Zinc yang kurang dari tubuh dapat mengakibatkan repitalisasi usus menjadi lambat, vili kekebalan usus berkurang. Vili yang muda tersebut tidak mampu menyerap nutrisi yang dibutuhkan oleh tubuh sehingga gizi anak dapat menjadi buruk (Riskiyah, 2017).

Air susu ibu (ASI) dan makanan yang sehat juga harus diberikan untuk mencegah penurunan berat badan dan menggantikan nutrisi yang hilang. Makanan bergizi dan atau ASI harus sesegera mungkin diberikan bila anak sudah mengalami perbaikan sebagai pencegahan terjadinya gangguan gizi, menstimulasi perbaikan usus dan mengurangi derajat penyakit (Rendang Indriyani \& Putra, 2020). Dalam penelitian Omo Sutomo, dkk tahun 2018 menyatakan bahwa ibu yang tidak memberikan ASI secara eksklusif pada bayinya memiliki resiko lebih dari 8 kali lebih besar untuk mengalami diare dibandingkan dengan ibu yang memberikan ASI eksklusif (Sutomo, Sukaedah, \& Iswanti, 2020).

Madu diberikan sebagai salah satu terapi komplementer dalam penanganan diare. Dalam Penelitian yang dilakukan oleh Dwi Nurmaningsih tahun 2019 menunjukkan adanya pengaruh pemberian madu terhadap penurunan frekuensi $B A B$ dan perubahan konsistensi feses pada anak balita (Nurmaningsih \& Rokhaidah, 2019).

Madu memiliki manfaat yang tinggi salah satunya dapat mengatasi diare karena madu memiliki efek antibakterial, pengganti cairan tubuh, serta dapat bekerja sebagai agen anti inflamasi dalam mencegah kerusakan usus (Sakri, 2015). Dalam penelitian Sharif, dkk tahun 2017 juga menyebutkan bahwa madu dapat ditambahkan ke larutan oralit untuk mempersingkat masa diare akut pada anak (Sharif, A., et al, 2017). Madu dapat mengendalikan berbagai jenis bakteri dan penyakit menular Dengan penyuluhan kesehatan menjadi salah satu upaya untuk meningkatkan pengetahuan orang tua dalam melakukan penanganan diare dengan baik.

\section{SIMPULAN DAN SARAN}

Hasil kegiatan penyuluhan kesehatan mengenani penanganan diare pada anak usia 2-16 tahun didapatkan hasil $14(93,3 \%)$ orang tua (ayah/ibu) yang memahami mengenai penanganan diare pada anak dan 1 (6,6\%) orang tua (ayah/ibu) yang aktif bertanya dalam kegiatan.

\section{UCAPAN TERIMAKASIH}

Kami ucapkan terimakasih kepada beberapa pihak, terutama kepada kampus kami STIKes Yatsi, kepada Lembaga Penelitian Pengabdian kepada Masyarakat (LPPM) STIKes Yatsi. Tidak lupa juga kepada para peserta yang sudah berkenan hadir dan mengikuti kegiatan pengabdian masyarakat mengenai penanganan diare pada anak sehingga kegiatan dapat berjalan dengan lancar.

\section{DAFTAR RUJUKAN}

Ariani. (2016). Diare Pencegahan dan 
Pengobatan. Yogyakarta: Nuha Medika. Arsurya, Y., Rini, E. A., \& Abdiana, A. (2017). Hubungan Tingkat Pengetahuan lbu tentang Penanganan Diare dengan Kejadian Diare pada Balita di Kelurahan Korong Gadang Kecamatan Kuranji Kota Padang. Jurnal Kesehatan Andalas, $6(2), \quad 452$. https://doi.org/10.25077/jka.v6i2.720

Humrah, lis, S., Amelia, W., \& Mukarramah. (2018). Gambaran Pengetahuan Ibu Balita Dalam Penanganan Awal Balita Diare Di Desa Bone Kec. Bajeng Kab. Gowa Tahun 2017. Jurnal Bidan "Midwife Journal," 5(01), 1-7.

Kemenkes RI. (2017). No Title. Profil Kesehatan Indonesia, Keputusan(Jakarta).

Nurmaningsih, D., \& Rokhaidah. (2019). Madu Sebagai Terapi Komplementer untuk Anak dengan Diare Akut. Jurnal Kesehatan Holistik, 3(1), 1-10.

Nursa'in, S. H. (2017). Gambaran Pengggunaan Oralit Dan Zink Pada Kasus Diare. Jurnal Farmasetis, 6(1), 25-28. Retrieved from www.stikeskendal.ac.id/journal/index.p hp/far/article/.../268/183/\%0ATr

Rendang Indriyani, D. P., \& Putra, I. G. N. S. (2020). Penanganan terkini diare pada anak: tinjauan pustaka. Intisari Sains Medis, $11(2), \quad 928$. https://doi.org/10.15562/ism.v11i2.848

Riskesdas, K. (2018). Hasil Utama Riset Kesehata Dasar (RISKESDAS). Journal of Physics A: Mathematical and Theoretical, 44(8), 1-200. https://doi.org/10.1088/17518113/44/8/085201

Riskiyah, R. (2017). Peranan Zinc Pada Penanganan Kasus Penyakit Diare Yang Dialami Bayi Maupun Balita. Journal of Islamic Medicine, 1(1), 2229.

https://doi.org/10.18860/jim.v1i1.4119

Sakri, F. . (2015). Madu dan Khasiatnya: Suplemen Sehat Tanpa Efek Samping. Yogyakarta: Diandra Pustaka Indonesia.

Sharif, A., Noorian, A., Sharif, MR., Ardakani, A.T., Zahedi, A., \& Kheirkhah, D. (2017). A Randomized Clinical Trial On The Effect of Honey in The Acute Gastroentritis. 5(6), 144-148.

Simona Ciccarell, Ilaria Stolfi, G. C. (2013). Management Strategies in The Treatment of Neonatal and Pedatric Gastroentritis. Infection and Drug Resistance.

Soenarto, S. S. (2011). Vaksin Rotavirus untuk pencegahan diare. Buletin Jendela Data \& Informasi Kesehatan.

Sutomo, O., Sukaedah, E., \& Iswanti, T. (2020). Hubungan Pemberian Asi Eksklusif Dengan Kejadian Diare Pada Bayi Di Wilayah Kerja Puskesmas Cibadak Kabupaten Lebak Tahun 2019. Jurnal Medikes (Media Informasi Kesehatan), 7(2), $\quad$ 403-410. https://doi.org/10.36743/medikes.v7i2. 250

Yunadi, F. D., \& Engkartini. (2020). Peningkatan Pengetahuan Tentang Pencegahan dan Penanganan Diare Dengan Larutan Oralit Pada Kader Kesehatan Di Desa Slarang. Jurnal Pengabdian Masyarakat Al-Irsyad (JPMA), 2(1), 63-71. 